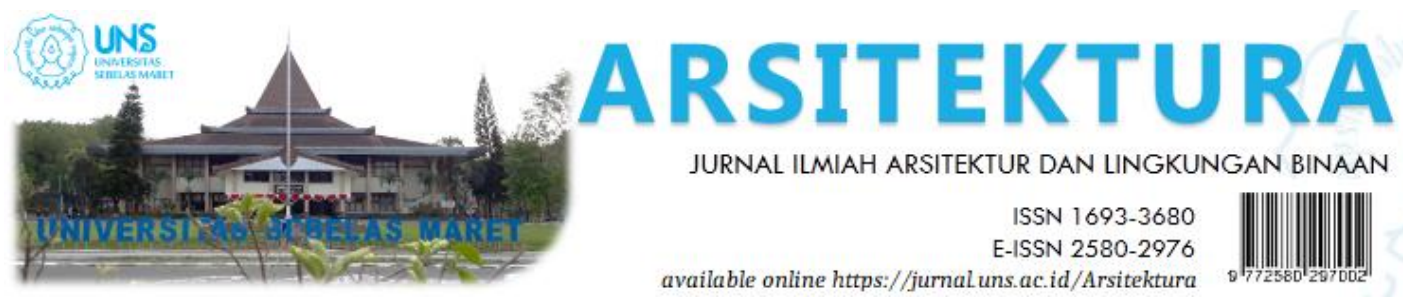

Volume 19 Issue 2 October 2021, pages: 239-248

\title{
TEKTONIKA PERPADUAN UNSUR JAWA DENGAN EROPA PADA PENDOPO DALEM KABUPATEN REMBANG
}

\section{The Tectonics of Javanese and Europe Elements in Pendopo Dalem Kabupaten Rembang}

\author{
Deny Setya Afriyanto ${ }^{1 *}$, Pusparini Dharma Putri ${ }^{2}$, Eugenius Pradipto ${ }^{3}$ \\ Program Studi Magister Arsitektur, Departemen Teknik Arsitektur dan Perencanaan Fakultas Teknik Arsitektur dan \\ Perencanaan, $U G M^{1}$ \\ deny.setya.afriyanto@mail.ugm.ac.id * \\ Program Studi Magister Arsitektur, Departemen Teknik Arsitektur dan Perencanaan Fakultas Teknik Arsitektur dan \\ Perencanaan, $U G M^{2}$ \\ Departemen Teknik Arsitektur dan Perencanaan, Fakultas Teknik Arsitektur dan Perencanaan, UGM ${ }^{3}$
}

DOI: https://doi.org/10.20961/arst.v19i2.50458

Received:April 26,2021 Revised:September 29,2021 Accepted:October 12,2021 Available online:October 30,2021

\begin{abstract}
Dalem Kabupaten Rembang (regent residence), including the Pendopo as part of the Dalem component, was built around 1750. This building has a traditional Javanese concept that combined colonial architectural elements. This study aims to see the philosophical aspects of the saka guru that may influence the tectonic fusion of Javanese and European elements. In order to know the tectonic aspect of the Pendopo Dalem Kabupaten, this research using qualitative methods, while data collecting is conducted through literature study and observation. The findings of this study can be seen from the philosophical aspect in the concept of the "papat kiblat lima pancer", where is reflected in the main structure of the saka guru (wooden material). Where functions as the main structure of the pendopo. Wooden material have given the aspect of its function which resists lateral forces (wind) to the overall construction. Meanwhile, the cement brick material on saka rawa and saka emper continuing the roof load to its foundation, used as bearing wall system.
\end{abstract}

Keywords: pendopo; saka; doria column; philosophy; bearing structure

\section{PENDAHULUAN}

Tingkat perkembangan kehidupan manusia ditandai dengan keberadaan bangunan fisik, di dalam bangunan fisik tersebut kemudian muncul nilai intrinsik kearifan lokal seperti terwujud dalam arsitektur bangunan tradisional Jawa (Ahimsa-Putra, 2008: 7). Secara garis besar kearifan bangunan tradisional Jawa dapat diurai menjadi kepercayaan, pengetahuan, etika sosial, dan rasa estetika (Ronald, 2005).
Secara umum, jenis arsitektur Jawa dibagi ke dalam lima bentuk dasar yaitu panggang pe, kampung, limasan, tajug, dan joglo. Dalam hierarki bangunan tradisional Jawa, joglo merupakan bentuk tertinggi dan dianggap paling indah. Bagi masyarakat Jawa, pada zaman dulu bangunan Joglo dianggap tidak boleh dimiliki oleh rakyat biasa, melainkan hanya diperuntukkan untuk rumah milik kaum priyayi atau bangsawan. 
Hal ini karena bentuk pada bangunan rumah Joglo tidak mudah ditiru, diangap paling rumit dan membutuhkan biaya yang cukup besar dalam proses pembangunannya (Ds, Slamet, 1985).

Falsafah hidup masyarakat Jawa menempatkan segala kegiatan yang bersifat kontras dengan sekelilingnya sehingga tercipta pola dualistik (Koentjaraningrat, 1980: 127 dalam Ronald, 2005: 72). Klasifikasi simbolik yang menyebutkan adanya dualitas tersebut juga tercermin ke dalam suatu bangunan dan bahkan menurut Tjahjono (1990) juga terdapat satu aspek lagi yaitu sentralitas. Jika dualitas membagi bagian rumah menjadi kanan-kiri, luar-dalam, sakral-profan, publik-privat maka sentralitas menunjukkan adanya pemusatan ruang. Dalam tata ruang bangunan, senthong merupakan pusat dari dalem, dalem merupakan pusat kesatuan pendopo, pringgitan dan dalem, pada akhirnya komposisi tersebut merupakan pusat keseluruhan komposisi bangunan dalam satu domain halaman. Mangunwijaya (1995, 107-111) dalam tulisannya yang dikutip oleh Prihani (2009: 14-15) menyebutkan bahwa susunan rumah bagi masyarakat Jawa, baik golongan kebanyakan maupun raja terbagi atas dua bagian, yaitu bagian yang bersifat privat, disebut dalem dan publik, disebut njaba atau pelataran, yang dikelilingi oleh pagar.

Kompleks Dalem Kabupaten Rembang beralamat di Jalan Gatot Subroto no. 8 Rembang. Kompleks bangunan tersebut saat ini difungsikan sebagai area perkantoran dan museum. Beberapa bangunan yang ada di dalam kompleks ini antara lain regol (gerbang pintu masuk), gedung eks Sekolah Kartini, bangunan utama, serta bangunan pemerintahan. Area perkantoran bertempat di sayap kanan dan kiri pada halaman depan kompleks Dalem Kabupaten, sedangkan bangunan utama ada pada bagian tengah. Seperti layaknya bangunan tradisional Jawa milik bangsawan, bangunan utama dalam kompleks ini berupa pendopo, pringgitan, dan dalem.

Pendopo merupakan suatu bangunan tradisional Jawa yang diperuntukkan sebagai area pertemuan/musyawarah. Istilah pendopo sendiri disadur dari bahasa Sansekerta dengan asal kata Mandapa yang berarti aula atau kubah, bersifat semi publik.
Ciri khas bangunan Joglo dapat dilihat dari adanya brunjungan yang memiliki tumpangsari. Bagian ini disokong oleh empat buah tiang utama atau yang disebut dengan saka guru dan dikelilingi oleh saka lainnya. Menurut Prijotomo (2006: 217) struktur saka guru merupakan tiang-tiang yang menjadikan dirinya sebagai tempat bagi sistem struktur balandarpengeret/pamidhangan. Tiang yang berada di saka guru terletak di sektor saka guru, saka yang terletak pada sektor penanggap disebut saka penanggap, dan begitu pula pada saka yang terletak di emper disebut sebagai saka emper.

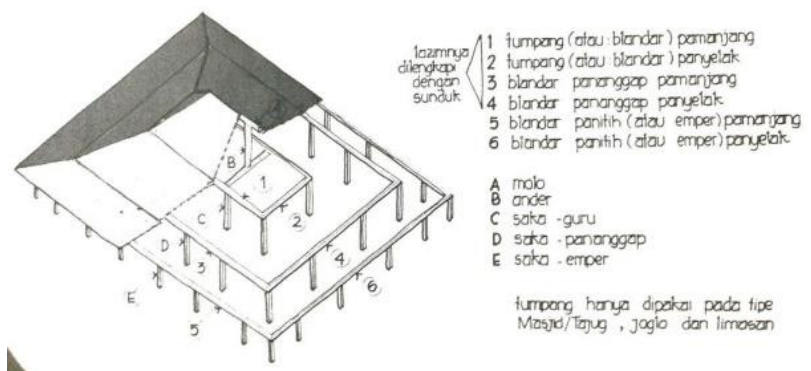

Gambar 1. Unsur Konstruksi Penting Bangunan Joglo

Sumber: Josef Prijotomo dan Murni Rachmawati (1995)

Pendopo yang berbentuk Joglo ini merupakan perkembangan bangunan tradisional Jawa yang terakhir dan sekaligus merupakan puncak keindahan dari arsitektur tradisional Jawa (K, Budi Tjahjono, 2015: 67).

Arsitektur Dalem Kabupaten mulai mengalami perubahan sejak adanya campur tangan pemerintah Hindia Belanda dalam proses pembangunannya. Hal ini seperti disampaikan oleh Sukesi (1985:13-14) yang menyatakan bahwa mulanya bangunan Dalem Kabupaten memiliki krobongan, namun setelah krobongan dianggap kuno dan tidak hygienis, kemudian krobongan tidak lagi dipakai. Pemerintah kolonial, melalui Burgerlijke Openbare Werken (BOW) alias jawatan Pekerjaan Umum (PU) pada zaman kolonial, juga melakukan banyak perubahan pada komponen bangunan pendopo seperti saka-nya yang diganti dengan pilar bergaya Yunani, kecuali pada Saka guru yang tetap menggunakan 
material kayu. Hal ini dapat dikaji melalui sudut pandang tektonika bangunan. Akar kata tektonika berasal dari kata tekton yang secara harafiah berarti pertukangan kayu atau pembangun. Tektonika juga seringkali dipandang sebagai seni dari pertemuan atau sambungan yang ditekankan pada teknik. Hal ini merujuk pula pada pengetahuan mengenai estetika sistem konstruksi bangunan yang bukan hanya bagian dari bangunan melainkan juga sebagai sebuah karya seni (Frampton, 1995 dalam Juniwati, 2003; Potter, 2004 dalam Kapilawi dkk, 2019).

Penggunaan elemen Eropa (kolonial) pada struktur pendopo menjadikan tektonika Pendopo Kabupaten menjadi menarik karena berbeda dengan model-model eksisting pendopo tradisional Jawa yang umumnya berbahan kayu secara keseluruhan. Lebih menarik lagi bahwa Pendopo Kabupaten Rembang masih mempertahankan material kayu pada struktur brunjung dan saka guru. Oleh karena itu perlu dilihat sejauh mana aspek filosofi pada saka guru memiliki pengaruh terhadap tektonika perpaduan unsur Jawa dengan Eropa?

\section{METODE}

Kajian tektonika pada Pendopo Kabupaten Rembang dilakukan dengan metode kualitatif. Penggunaan metode ini dimaksudkan untuk mendapatkan data yang nantinya akan dituangkan dalam bentuk deksriptif. Selain itu dalam proses pembuatan tulisan ini dilakukan dengan penalaran induktif. Penalaran induktif yaitu penalaran yang bergerak dari kajian fakta-fakta atau gejala-gejala khusus untuk kemudian disimpulkan sebagai gejala yang bersifat umum atau generalisasi empiris (Lincoln dan Guba, 1985: 40).

Pengumpulan data yang awalan menggunakan metode literature review atau telaah pustaka. Telaah pustaka merupakan kajian yang bersumber pada data sekunder (Sugiyono, 2012: 141). Pencarian pustaka yang dilakukan seputar berbagai penelitian yang berhubungan dengan arsitektur tradisional Jawa, khususnya pada pendopo dan penerapan elemen arsitektur Eropa (kolonial). Data yang dikumpulkan dalam proses telaah ini dikumpulkan dan dikompilasi sehingga menjadi suatu kesimpulan yang dapat menjelaskan mengenai aspek filosofi pada saka guru yang memiliki pengaruh terhadap tektonika bangunan yang memadukan unsur tradisional Jawa dan unsur Eropa (kolonial).

\section{HASIL DAN PEMBAHASAN}

\subsection{Pendopo Dalem Kabupaten Rembang}

Secara geografis Kabupaten Rembang berada di ujung timur laut Provinsi Jawa Tengah dan berada pada garis koordinat antara $111^{\circ} 00^{\prime}$ $111^{\circ} 30^{\prime}$ BT dan 6 $30^{\prime}$ - $7^{\circ} 6^{\prime}$ LS. Kabupaten Rembang diapit oleh Laut Jawa di sebelah utara dan Pegunungan Kendeng Utara serta Kabupaten Blora di sebelah selatan. Pada sisi barat wilayah ini berbatasan dengan Kabupaten Pati dan sebelah timur berbatasan langsung dengan Provinsi Jawa Timur. Pusat kota Kabupaten Rembang berada di wilayah pesisir yang berada di Kecamatan Rembang.

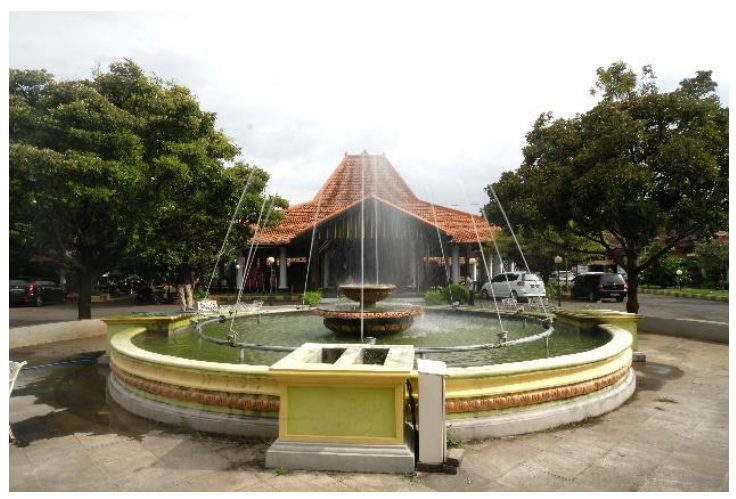

Gambar 2. Tampak depan Pendopo Dalem Kabupaten Rembang

Tahun dan proses pembangunan Dalem Kabupaten Rembang sejauh ini tidak diketahui secara pasti, namun diperkirakan bangunan pusat pemerintahan ini dibangun sekitar tahun 1750 yang mana merupakan pemindahan pusat ibukota yang sebelumnya berada di Lasem (Tim Ahli Cagar Budaya Kabupaten Rembang, 2018). Hal ini terkait dengan sejarah pengambilalihan kekuasaan di wilayah pesisir oleh $V O C$ dari pihak Mataram. Paska peristiwa Geger Pecinan yang terjadi pada 1740 , atau tepatnya pada tahun 1743 , VOC mengadakan perjanjian dengan Paku 
Buwana II untuk mengambil daerah di pantai utara Jawa Tengah termasuk di dalamnya adalah Rembang (Wijaya, 2017: 15).

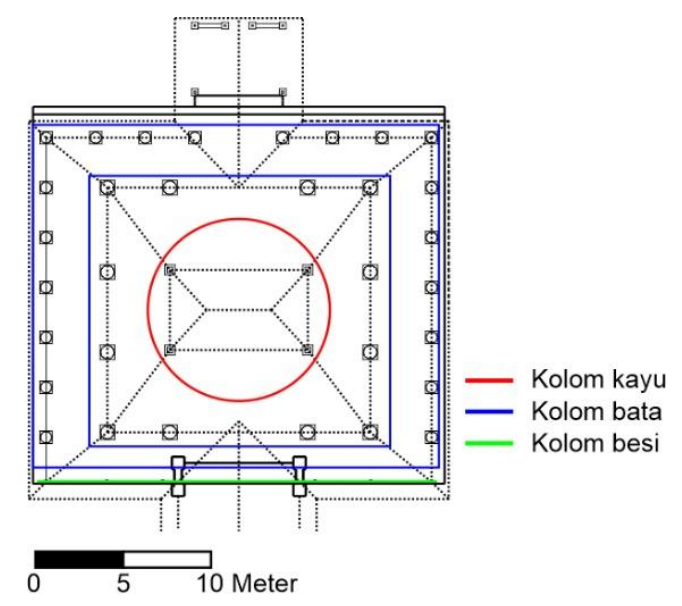

Gambar 3. Denah penempatan kolom pada Pendopo Dalem Kabupaten Rembang

Denah bangunan Joglo, termasuk Pendopo Dalem Kabupaten Rembang pada dasarnya berupa bujur sangkar hanya dengan empat tiang. Kemudian pada bagian sisi luarnya ditambahkan tiang-tiang yang lain sehingga dalam perkembangannya muncul denahdenah baru pada rumah Joglo. Penambahan tiang ini pada akhirnya tidak hanya bersifat tambahan saja melainkan menjadi satuan konstruksi yang kemudian memunculkan berbagai ragam Joglo (Ds, Slamet, 1985).

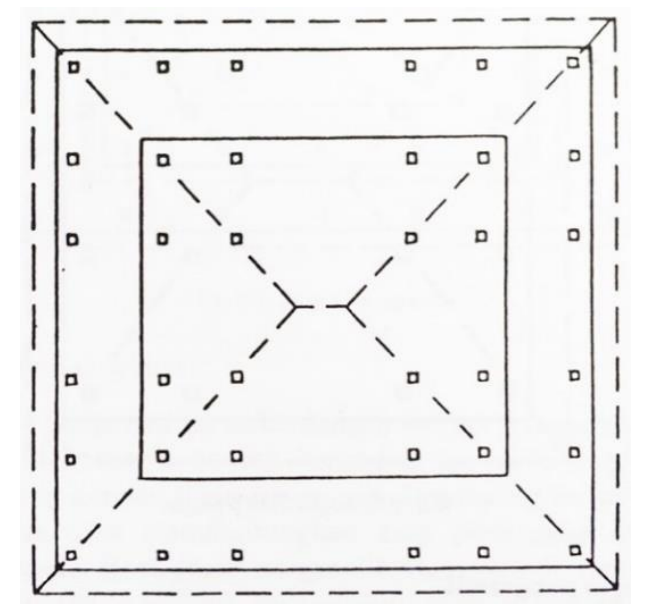

Gambar 4. Denah dasar pendopo joglo

Pendopo Kabupaten Rembang memiliki struktur bagian badan berupa empat saka guru, 12 saka rawa, sementara pada saka emper terdiri dari 20 kolom doria (material bata) di sisi utara-timur, dan barat ditambah dengan enam kolom besi dan kolom doria yang menghubungkan dengan sisi longkangan. Saka-saka tersebut lain dari kebanyakan bangunan tradisional Jawa yang secara keseluruhan menggunakan material kayu, melainkan menggunakan material bata pada saka rawa dan saka emper. Saka dengan material kayu hanya digunakan pada bagian saka guru saja. Saka guru sendiri merupakan elemen struktur yang dianggap penting dalam konsep kosmologi Jawa karena pilarnya membentuk pajupat/mancapat sebagai struktur utama. Keempat saka guru juga merupakan unsur vertikal yang biasanya diwujudkan dalam bangunan masjid seperti pada atap tajug (Adityaningrum, Pitana, dan Setyaningsing, 2020: 58). Namun demikian pada tingkatan bangunan tertinggi dalam arsitektur tradisional Jawa yakni joglo, saka guru ini juga merupakan penyusun utama unsur vertikal baik secara struktur maupun filosofi.

Saka rawa dan saka emper pada Pendopo Dalem Kabupaten Rembang menerapkan langgam Eropa. Kolom bergaya doria ini memiliki perbedaan antara saka rawa dan saka emper. Pada bagian saka rawa memiliki ornamen berupa cekungan garis-garis vertikal sedangkan pada saka emper polos.

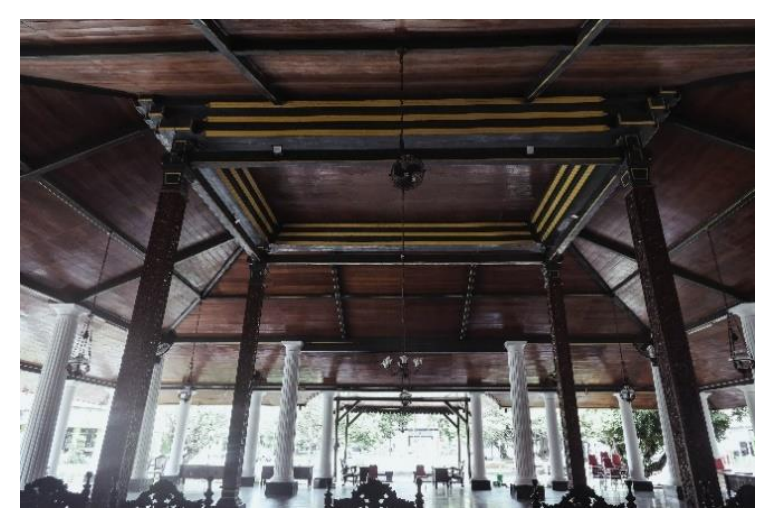

Gambar 3. Saka guru dan struktur tumpang sari pada Pendopo Dalem Kabupaten Rembang

Penggunaan kolom doria ini merupakan wujud dari situasi politik pemerintahan kolonial yang saat itu mengharuskan penguasa bergaya hidup, berbudaya serta membangun gedung dan rumah tempat tinggalnya berbeda dengan rumah pribumi. Pandangan ini ditujukan untuk memberikan persepsi berbeda antara kedudukan dan jatidiri penguasa dengan masyarakat (Budiwiyanto, 2008: 10). 
Hal ini didukung oleh pendapat Soekiman (2000: 303) yang menyatakan bahwa tiang yang bergaya doria memiliki simbol kekuatan, sesuai dengan jiwa bangsa Doria yang berjiwa militer. Gaya doria menghendaki bentuk bangunan yang diciptakan tampak kokoh, kuat, perkasa, sekaligus juga dapat dijadikan sebagai lambang kekuasaan, dengan demikian gaya doria sangat cocok sebagai hiasan bangunan pemerintah atau penguasa.

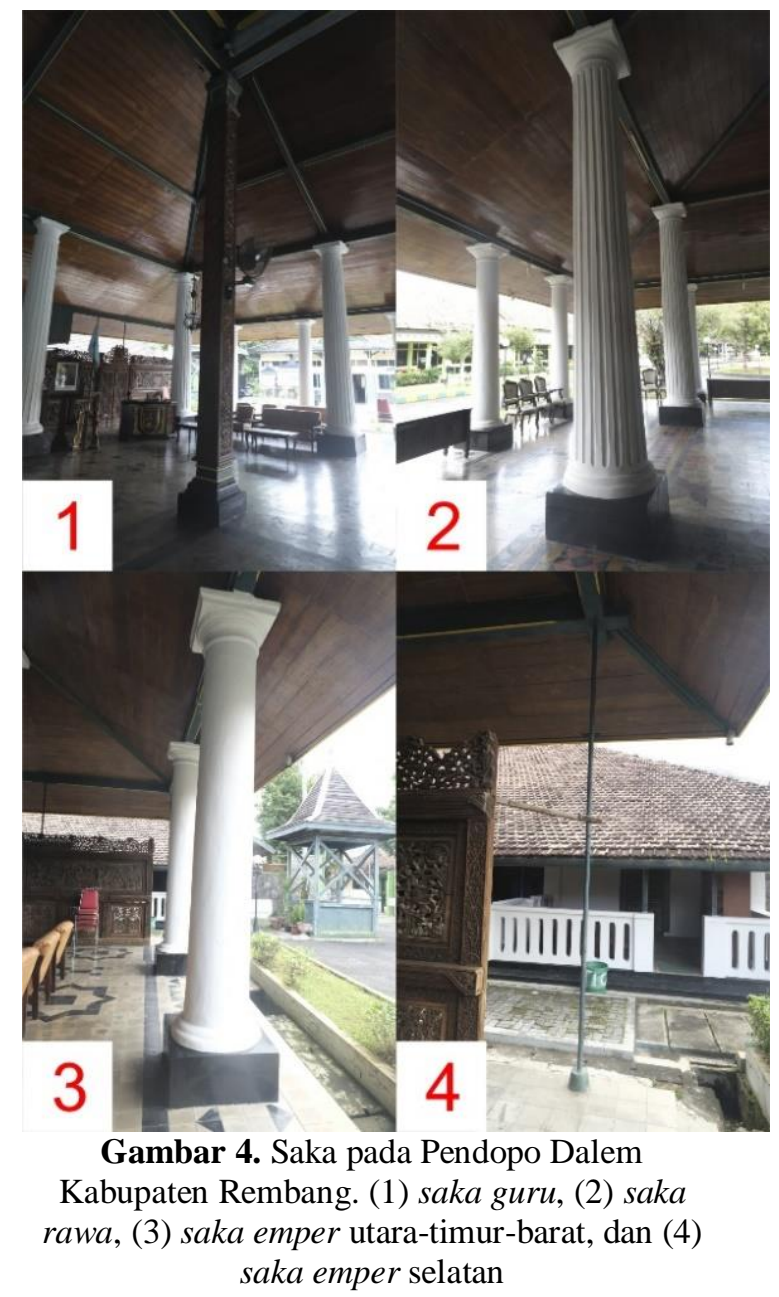

\subsection{Tektonika (Nilai Filosofi dan Konstruksi) Pendopo Dalem Kabupaten Rembang}

Bangunan Joglo pada umumya dan pendopo pada khususnya menggunakan material kayu, baik pada strutkur utama maupun komponen pengisi bangunan. Material saka guru dan saka emper pada bangunan pendopo tradisional menggunakan material kayu, namun terjadi pergeseran material seiring dengan masuknya pengaruh arsitektur Kolonial. Penggunaan material kayu sebagai material utama bangunan Joglo merupakan suatu bentuk kearifan lokal membaca alam. Diketahui kayu memiliki kekuatan tekan dan tarik yang baik, sehingga cocok digunakan sebagai struktur utama bangunan pendopo dengan struktur atap yang masif dan berat.

Jika dilihat dalam sudut pandang horizontal pada keseluruhan komponen rumah Joglo, pembagian ruang rumah terdiri lima ruang. Ruang dalem posisinya tepat di tengah, diapit bagian depan oleh ruang pendopo-pringgitan, dan diapit bagian belakang oleh ruang gadripawon. Sementara bagian kiri dan bagian kanan berupa gandhok kiri dan gandhok kanan. Struktur ini merupakan transformasi dari struktur alam (kosmologi) berupa empat arah mata angin, yaitu: (U) utara, (S) selatan, (T) timur dan (B) barat, dan satu titik pusat di tengah, yang merupakan persinggungan ke empat arah mata angin ter-sebut. Dalam terminologi Jawa struktur ini disebut papat kiblat limapancer. Hal ini merupakan konsep spiritual yang tercermin pada bangunan yang didasarkan pada pola tengah atau pusat yang bermakna sakral. Pola itu juga termanifestasi dalam struktur satu di tengah diapit dua lainnya, atau pola struktur di depan dan belakangnya, atau di kiri dan kanannya, seperti tercermin dalam pola papat kiblat lima pancer (Darsiti, dalam Djono, 2012: 272).

Dalam konsep Jawa, susunan memusat yang dikelilingi empat kolom (saka guru) yang bertalian dalam satu kesatuan struktur merupakan bentuk konkret pandangan orang Jawa tentang papat kiblat lima pancer. Struktur tersebut menggambarkan mandala yang susunannya meliputi empat anasir yang di tengahnya terdapat pancer sebagaimana dikatakan orang ahli bangunan Jawa (Djono, dkk, 2012: 274):

"bahwa semua yang diciptakan Tuhan Yang Esa selalu bermula dari empat sudut dan satu yang berasal dari tengah yang orang Jawa menyebut empat kiblat lima pancer. Semua kejadian berasal dari lima penjuru tersebut. Rumah joglo adalah merupakan wujud yang dianggap mikro tetapi juga makro bagi alam raya. Ia merupakan peniruan alam, maka harus berpijak 
pada pedoman pajupat dimana dalem adalah titik pusatnya yang dikelilingi bangunan lainnya."

Adanya sentralitas dalam tata ruang bangunan Jawa juga disampaikan oleh Tjahjono (1990) seperti dikutip oleh Suprijanto (2002: 11) yang menyatakan bahwa ada pemusatan tata ruang bangunan di mana senthong merupakan pusat dari dalem, dalem merupakan pusat dari pendopo, pringgitan, dan dalem, dan komposisi-komposisi tersebut merupakan pusat dari keseluruhan bangunan dalam satu domain bangunan. Jika dalem merupakan pusat dari keseluruhan ruang maka adanya konsep sentralitas pada bangunan pendopo juga dapat dijumpai dari adanya filosofi papat kiblat lima pancer. Hal ini menunjukkan bahwa di dalam pendopo sendiri memiliki aspek sentralitas yang terdapat pada struktur empat saka guru yang secara vertikal ke atas hingga bagian kepala bangunan.

Sentralitas saka guru tidak hanya cerminan filosofi kiblat lima pancer, hal tersebut merupakan implementasi pemahaman teknologi konstruksi bangunan. Saka guru dengan tumpang sari-nya merupakan struktur utama bangunan yang memikul beban utama bangunan sebelum diteruskan ke komponen struktur lainnya. Konstruksi bangunan sendiri harus berhasil dalam menahan gaya yang mempengaruhi kestabilan bentuk bangunan. Melihat sifat kayu yang tahan terhadap gaya tarik dan tekan, merupakan suatu hal yang tepat saka guru posisinya tidak digantikan dengan material lain yang tidak memiliki kesamaan sifat. Sebagai contoh pada kasus gempa bumi yang melanda Daerah Istimewa Yogyakarta pada 2006 silam. Dalam peristiwa bencana tersebut, keberadaan material kayu pada saka guru menjadi sangat penting dalam menahan gaya lateral. Dengan tetap mempertahankan keberadaan struktur kayu pada bagian saka guru dan tumpang sari-nya, Pendopo Kabupaten Rembang berhasil menunjukan keberhasilan pemahaman struktur konstruksi, dimana saka guru masih menggunakan kayu namun saka rawa dan emper sudah beralih menggunakan material batu bata tanpa tulangan (bearing wall system) serta kolom besi.

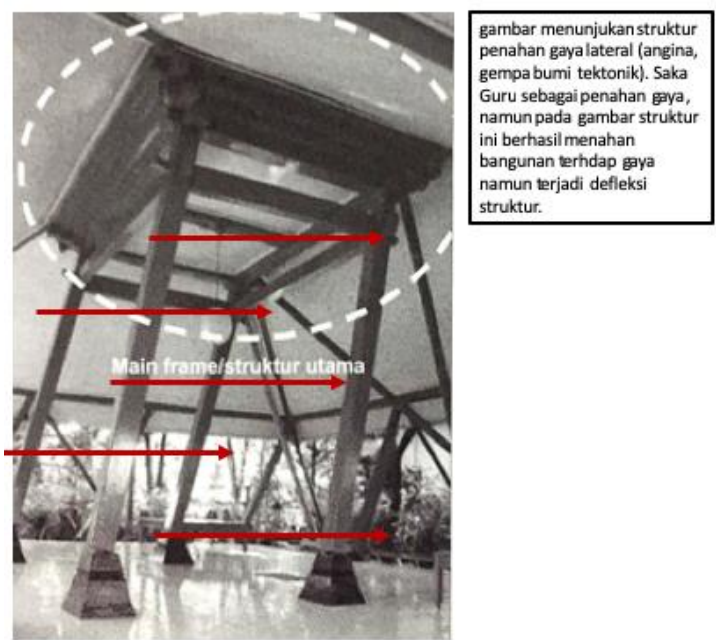

Gambar 5. Saka guru pasca gempa bumi Bantul 2006, Kotagede

Sumber: Pedoman Pelestarian Rumah Kotagede (2007), dimodifikasi penulis skema gaya lateral

Dalam skala vertikal, bangunan tradisional Jawa terdiri dari bagian kaki (umpak dan bebatur), badan (tiang dan dinding), dan bagian atas kepala atau atap. Skala vertikal ini merupakan struktur tegak yang berupa oposisi antara dunia transenden (immaterial) dengan dunia imanen (material). Lebih jauh, dalam mistik kejawen struktur atap merupakan puncak yang merepresentasikan keghaiban (Djono, dkk, 2012: 272). Keberadaan saka guru yang masih menggunakan material kayu pada Pendopo Dalem Kabupaten Rembang menunjukkan adanya konsep tradisi Jawa yang masih memegang teguh prinsip bangunan Jawa. Prinsip ini tidak hanya dilaksanakan dalam segi filosofisnya saja melainkan juga pada aspek tektonika bangunan yang mana masih dapat dilihat adanya struktur bagian atap yang secara keseluruhan masih menggunakan material kayu. Hal ini dapat dilihat pada struktur jurai dan blandar. 


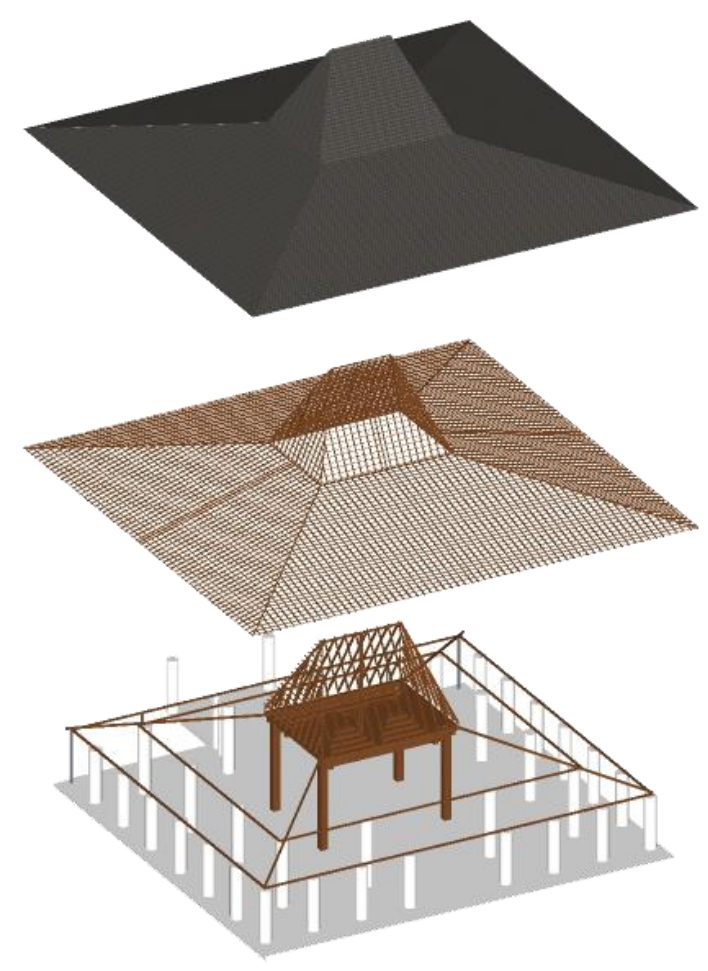

Gambar 6. Aksono Struktur Pendopo Kabupaten Rembang

Perlakuan penggunaan material kolom dilakukan berbeda pada saka rawa dan saka emper. Dominasi penggunaan material bata merah umumnya tidak dijumpai pada bangunan tradisional Jawa sebelum masa kolonial. Seperti halnya pada bagian pendopo bangunan, penggunaan material kolom pada bangunan tradisional Jawa menggunakan bahan yang mudah dijumpai di sekitar, seperti bambu dan kayu tahunan. Kayu tahunan yang dimaksud adalah kayu yang memiliki usia panjang dan tidak mudah dimakan rayap. Selain itu kayu ini biasanya mempunyai warna-warna yang sangat indah, misalnya coklat muda atau coklat tua dari kayu jati, hitam dari kayu glugu, dan kuning dari kayu nangka (Ismunandar, 1997: 45 dalam Wijaya, 2017: 54-55). Hal ini selaras dengan apa yang disampaikan oleh Rapoport (1969) di mana bentuk arsitektur merupakan bagian dari adaptasi lingkungan.

Sebagai wujud adaptasi terhadap lingkungan alam maupun sosial, dapat dipastikan Kompleks Pendopo Kabupaten Rembang secara keseluruhan terpengaruh dengan gaya arsitektur Eropa (kolonial). Hal ini nampak pada mayoritas elemen bangunan menggunakan teknologi material bata dan semen, hal ini tentu tidak lazim di masyarakat Jawa Tradisional pada masanya. Pengubahan material pada bangunan menunjukan usaha akulturasi gaya arsitektur namun tetap mempertahankan gaya "Jawa", yaitu dengan tetap menggunakan kayu sebagai material saka guru. Secara nilai filosofi ini juga dapat diartikan, meskipun mayoritas komponen kompleks Pendopo Rembang sudah menggunakan material bata semen, namun pancer-nya masih tetap Jawa (kayu).

Jika menelisik sisi geografis Indonesia, Jawa merupakan wilayah yang rawan gempa sehingga menghasilkan sistem struktur bangunan yang berbeda dengan bangunan di daerah lainnya. Sistem struktur oleh masyarakat dimaknai sebagai sesuatu yang penting dalam kaitannya dengan perlindungan bagi penghuninya, memenuhi rasa aman dan nyaman sehingga penghuni dapat melakukan kegiatan selayaknya menjalankan kehidupan sebagai manusia (Sudarwanto dan Murtono, 2013: 38). Pendopo Kabupaten Rembang memiliki sistem struktur yang menahan beban lateral dengan kuncian saka guru dan tumpang sari. Sistem struktur ini menitik beratkan beban bangunan di pusat (saka guru) dan menghasilkan kestabilan bangunan terhadap gaya lateral yang baik. Seperti diketahui bangunan joglo memiliki konstruksi yang berat sehingga memerlukan konstruksi yang kuat pula. Selain itu inti kekuatan struktur bangunan pendopo juga diwujudkan pada struktur rong-rongan (umpak-saka guru blandar) dan kekakuannya diperoleh dengan penerapan struktur rangka ruang (saka samping-blandar-usuk), dan kombinasi struktur ini dianggap sebagai struktur core in frame (Prihatmaji, 2007: 2-3).

Saka guru beserta tumpang sari dan struktur kayu lainnya seperti blandar di Pendopo Dalem Kabupaten Rembang memiliki peran penting dalam menahan goncangan jika dibandingkan dengan struktur saka lainnya. Penempatan saka guru dengan material kayu dapat meminimalisir dampak kerusakan berat pada saat goncangan. Sistem struktur pada daerah rawan gempa didasarkan atas prinsip elastisitas/kelenturan. Penggunaan ikatan antar elemen ini diaplikasikan melalui sistem bongkar pasang dengan adanya purus, Sistem 
purus inilah yang mendukung bangunan supaya tidak roboh apabila terkena gaya lateral. Gaya tersebut kemudian dieliminasi pada sambungan antara saka guru yang di situ terdapat 'tumpang sari' sehingga momen pada umpak adalah nol. (Sudarwanto dan Murtono, 2013: 38).

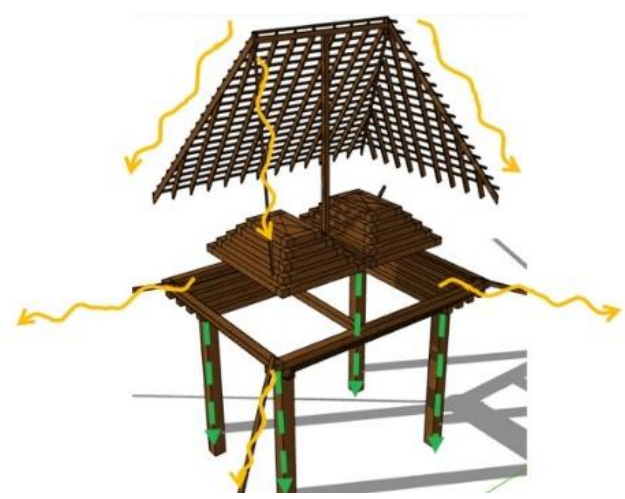

Gambar 7. Komponen Struktur Atap

(Tumpangsari) dan penyaluran beban atap

Pemilihan perbedaan struktur antara saka guru dan saka emper ini selain dimaksudkan bahwa ada aspek filosofi papat kiblat lima pancer juga pada aspek kekuatan struktur bangunan yang disesuaikan dengan kondisi geografis setempat. Sementara itu, penggunaan struktur kolom bergaya Eropa pada saka rawa dan saka emper lebih dimaksudkan sebagai tampilan belaka, disamping secara ketahanan material bersifat untuk menahan beban atap (bearing wall system) dan untuk menjaga kekakuan bangunan. Bagian ini lebih ditekankan pada pembebanan bagian atap dari pada pembebadan lateral. Pada dasarnya struktur kolom ini menopang struktur bagian penanggap dan penitih sehingga lebih berfungsi sebagai penahan beban, dan meneruskan beban dari atas ke bawah (atap ke fondasi). Selain itu, seperti disinggung sebelumnya bahwa penggunaan kolom doria juga menambah kesan kokoh dan merupakan simbol kekuasaan/penguasa. Oleh karena itu penggunaan kolom ini di bangunan pemerintahan setingkat pejabat daerah pada waktu itu memberi kesan kekuasaan yang kuat.

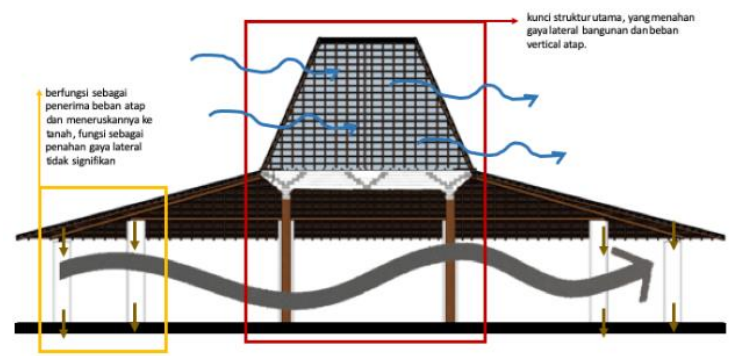

Gambar 8. Skema pembebanan statis (bangunan) dan dinamis (angin) pada Pendopo Dalem Kabupaten Rembang

\section{KESIMPULAN}

Pendopo Kabupaten Rembang memiliki perpaduan komponen struktur yang mencerminkan langgam budaya Jawa dan Eropa. Hal ini tercermin dari adanya perbedaan material pada komponen struktur kolom pendukung (saka rawa, saka emper) jika dibandingankan dengan material pendopo pada umumnya sementara pada bagian saka guru menggunakan material kayu seperti pada bangunan joglo pada umumnya. Perbedaan penggunaan material pada komponen struktur, struktur utama (saka guru) dengan struktur pendukung (saka rawa dan saka emper) ini tidak sekadar bagian konstruksi bangunan yang memberi kesan gaya arsitektur Eropa saja melainkan juga terdapat nilai-nilai di dalamnya.

Telah dijelaskan pendopo memiliki filosofi papat kiblat lima pancer yang tercermin pada saka guru yang berfungsi sebagai struktur utama pendopo yang menahan gaya lateral (angin) terhadap konstruksi keseluruhan. Fakta lain berdasar data lapangan terdapat perbedaan material tiap komponen struktur, pada saka guru (kayu) sebagai struktur utama dan saka rawa (bata) juga saka emper (bata/logam) sebagai struktur pendukung. Perbedaan ini nyatanya bukan hanya untuk memberi kesan gaya arsitetkur Eropa (kolonial) saja namun secara ketahanan dan konstruksi bangunan juga memiliki suatu pembelajaran. Hal tersebut menunjukan ketepat gunaan teknologi (material bangunan) dalam menanggapi lingkungan. Penggantian material dari kayu menjadi bata juga menunjukan pemahaman teknologi yang baik oleh masyarakat pada masa pendudukan kolonial. Aspek ini oleh pembangunnya dipertahankan baik dari segi nilai maupun 
fungsi strukturnya. Sementara di sisi lain, penggunaan material selain kayu pada struktur saka rawa dan saka emper di sini lebih berfungsi sebagai penahan beban atap.

Lebih jauh lagi, penggantian material dari kayu menjadi bata juga menunjukan adanya pemahaman teknologi yang baik oleh masyarakat pada masa pendudukan kolonial. Aspek ini oleh pembangunnya dipertahankan baik dari segi nilai maupun fungsi strukturnya. Sementara di sisi lain, penggunaan material selain kayu pada struktur saka rawa (bata) dan saka emper (bata/besi) di sini berfungsi sebagai penahan beban atap disamping maksud memberikan nilai tektonika arsitektur Eropa.

\section{REFERENSI}

Adityaningrum, Dewi, dkk. (2020). "Arsitektur Jawa Pada Wujud Bentuk dan Ruang Masjid Agung Surakarta," dalam Sinektika Jurnal Arsitektur, Vol. 17, No. 1, 1 Januari 2020, Hal:54-60.

Budiwiyanto, Joko. 2008. "Gaya Arsitektur Yunani Kuno dan Pengaruhnya Terhadap Seni Bangunan di Indonesia," dalam Ornamen, Vol. 5, No. 2, Hal: 1-15.

Darsiti. (1989). Kehidupan Dunia Kraton Surakarta 1830- 1939. Yogyakarta: Tamansiswa.

Djoko, dkk. (2012). "Nilai Kearifan Lokal Rumah Tradisional Jawa. Humaniora," dalam Humaniora, Vol. 24, No. 3, Oktober 2012, Hal 269-278.

Djono, Tri Prasetyo Utomo, Slamet Subiyantoro. (2012). "Nilai Kearifan Lokal Rumah Tradisional Jawa", dalam Humaniora, vol 24 hal: 269 - 278.

Ds, Slamet. (1985). Arsitektur Tradisional Daerah Jawa Tengah. Semarang: Departemen Pendidikan dan Kebudayaan, Direktorat Jendral Kebudayaan, Direktorat Sejarah dan Nilai Tradisional.

Handinoto. (2010). Arsitektur dan Kota-kota di Jawa pada Masa Kolonial. Yogyakarta: Graha Ilmu

Juniwati, Anik, dkk. (2003). "Perlunya Pengetahuan Tektonika pada Pengajaran Struktur di Arsitektur," dalam Dimensi Teknik Arsitektur. Vol 31, No. 2, Hal 120123.
Kapilawi, Yohanes W.D, dkk. (2019). "Kajian Tektonika Arsitektur Rumah Tradisional Sabu di Kampung Adat Namata," dalam Jurnal Gewang, Vol 1, No. 1, Hal: 8-13.

Muljadinata, Albertus S. dan Antariksa. (2017). "Penerapan Konsep Tradisional Pendopo Bangunan SMA Van Deventer Karya Karsten," dalam Seminar Nasional Jelajah Arsitektur Tradisional 2017. Medan.

Musman, Asti. (2017). Filosofi Rumah Jawa: Mengungkap Makna Rumah Orang Jawa. Yogyakarta: Pustaka Jawi.

Prihatmaji, Yulianto P. (2007). "Perilaku Rumah Tradisional Jawa "Joglo" Terhadap Gempat," dalam Dimensi Teknik Arsitektur Vol. 35, No. 1, Juli 2007, Hal: 1-12.

Prijotomo, Josef. (2006). (Re)Kontstruksi Arsitektur Jawa: Griya Jawa Tanpa Tulisan. Surabaya: PT. Wastu Lanas Grafika.

Prijotomo, Josef dan Murni Rachmawati. (1995). Petungan: Sistem Ukuran dalam Arsitektur Jawa.Yogyakarta: Gadjah Mada University Press.

Ronald, Arya. (1988). Manusia dan Rumah Jawa. Yogyakarta: Penerbit JUTA UGM.

. (2005). Nilai-nilai Arsitektur Rumah Tradisional Jawa. Yogyakarta: Gadjah Mada University Press.

Santosa, Adi, Murni Rachmawati, Vincentius Totok Noerwasito. (2020). "Hibriditas Tektonika Arsitektur Joglo", dalam Prosiding Seminar Ikatan Peneliti Lingkungan Binaan Indonesia (IPLBI), vol 4 hal: $088-095$.

Laporan Penelitian. Fakultas Teknik, Jurusan Arsitektur, Universitas Gadjah Mada. Yogyakarta.

Sudarwanto, Budi dan Murtomo, Bambang Adji. (2013). "Studi Struktur dan Konstruksi Bangunan Tradisional Rumah 'Pencu' di Kudus," dalam Jurnal Lingkungan Binaan Indonesia, Vol. 2, No. 1, Januari 2013, Hal: 35-42.

Sugiyono. (2012). Memahami Penelitian Kualitatif. Bandung: ALFABETA

Sukesi. (1985). "Bupati Pesisiran (Akhir Abad 19 Sampai Permulaan Abad 20)", Proyek Penelitian dan Pengkajian Kebudayaan 
Nusantara (Javanologi). Direktorat Jenderal Kebudayaan. Yogyakarta.

Suprijanto, Imam. (2002). "Rumah Tradisional Osing: Konsep Ruang dan Bentuk," dalam Dimensi Teknik Arsitektur Vol. 30, No. 1, Juli 2002, Hal: 10-20.

Umah, Rois Ainul dan Tian Fitriara Huda. (2017). "Pergeseran Bentuk dan Fungsi Rumah Joglo di Wilayah Banyuwangi", dalam Prosiding Pendidikan Budaya dan Sejarah: "Dibalik Revitalisasi Budaya".

Wulur, Fanny Alfrits, dkk. (2015). "Gaya Bangunan Arsitektur Kolonial pada Bangunan Umum Bersejarah di Kota Manado", dalam Sabua, Vol. 7, No. 1, Hal: 371.

Yuwanti, Sri. (2016). "Penggunaan Petungan dalam Pembangunan Rumah Tinggal Masa Kini sebagai Aspek TangibleIntangible Kebudayaan Masyarakat Pati Modern", dalam Prosiding Temu Ilmiah IPLBI, Hal: 095 - 104. 